\title{
Impact of Textile and Fertilizer Industry Effluents on Cytology of Root Meristem Cells of Hordeum vulgare L. Plant
}

\author{
Pramod Kumar Tandon*, Induja Tripathi and Kumkum Mishra \\ Department of Botany, University of Lucknow, Lucknow (U.P.), India - 226007
}

\begin{abstract}
Cytotoxic effects of effluents of both sugar and textile industries were studied in the root meristem cells of Hordeum vulgare plants. A comparative investigation on the somatic cells have been made on the basis of cytological observations such as mitotic index and other chromosomal abnormalities. Result of the present study indicated that both the industrial effluents have inhibitory effect on mitotic index and induced several chromosomal abnormalities.
\end{abstract}

Keywords: Cytotoxic effect, Industry effluents, Root meristem, Hordeum vulgare, Somatic cells, Mitotic index, Chromosomal abnormalities.

\section{Introduction}

Almost all industries generate hazardous wastes. They usually contain complex mixture of chemical and substantially contaminate ground and surface water reservoirs which are used for drinking purpose (Mumtaz, 1995; Dewhurst et al., 2002; Chandra et al., 2005) and might become hazardous to human health by inducing genetic alterations. Plant systems can detect a wide range of genetic damages including gene mutation and chromosome aberration (Maluzynska and Juchimiuk, 2005). Plant roots are extremely useful in biological testing. Therefore, the observation of root tip constitutes a rapid and sensitive method for environmental monitoring. Thus Hordeum root tips have been used for this study.

\section{Materials and Methods}

Seeds of Hordeum vulgare were used as test material which were soaked in tap water for $24 \mathrm{hrs}$ and allowed to germinate when their root length became $1-1.5 \mathrm{~cm}$, were transferred to petridishes containing effluents of both textile and fertilizer industry, respectively of different concentration (25, 50, 75 and 100\%). After $24 \mathrm{hrs}$, roots were washed and fixed in fresh and chilled Carnoy's fluid containing 1:3 acetic acid alcohol and put in refrigerator $\left(4^{\circ} \mathrm{C}\right)$. These root tips were stored in $90 \%$ alcohol and were used for preparing squashes. Mitotic squash preparation was made by the method of Darlington and La Cour (1976). Data were analysed by analysis of variance (ANOVA) and compared for level of significance by Duncan's Multiple Range Test.

\section{Results and Discussion}

Various concentrations of textile fertilizer industry effluent $(25,50,75$ and $100 \%$ each) were used to demonstrate the effect on mitotic index in $H$. vulgare at $24 \mathrm{hr}$ was 6.183 in control whereas after treatment it was $4.148,3.565,2.051$ and 1.393 at different concentrations of effluent (Table 1), indicating that frequency of chromosomal and mitotic aberration were increased with increase in concentration of effluent. The percentage of chromosomal aberration at $24 \mathrm{hr}$. It was 3.75, 7.32, 11.54 and 15.00 at different concentrations of textile industry effluent found in control. In the same effluent the percentage of mitotic aberrant cells at $24 \mathrm{hr}$ was 6.870 in control and 5.480, 9.244, 19.700 and 28.570 at different concentration of effluent (Table 1). 
Table 1 Mitotic index and percentage of different abnormalities in root meristem cells of Hordeum vulgare L. treated with different concentrations of textile industry effluent for 24 hour.

\begin{tabular}{|c|c|c|c|c|c|c|c|c|c|c|c|c|c|c|c|c|}
\hline \multicolumn{4}{|c|}{ Mitotic index (\%) } & \multicolumn{5}{|c|}{ Chromosomal aberration } & \multicolumn{8}{|c|}{ Mitotic aberration } \\
\hline 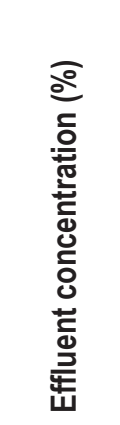 & 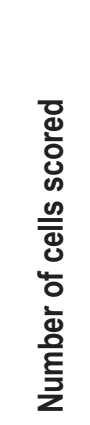 & 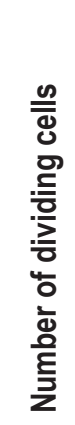 & 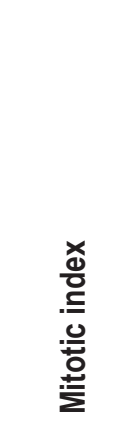 & 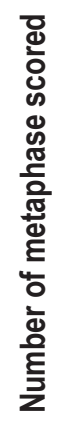 & 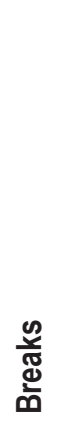 & 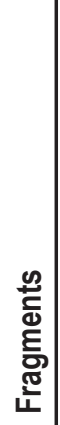 & 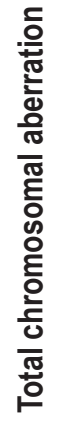 & 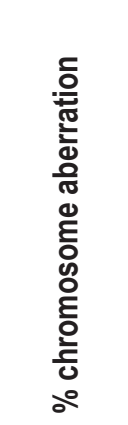 & 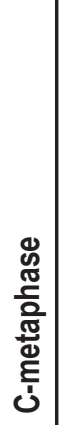 & 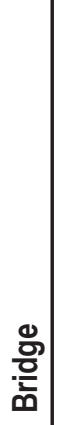 & 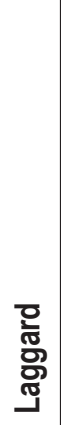 & 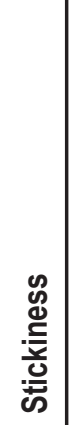 & 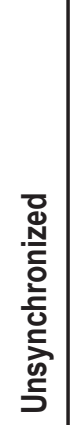 & 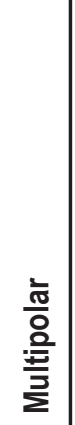 & 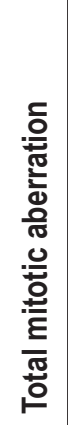 & 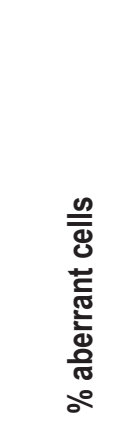 \\
\hline Control & 3720 & 230 & $\begin{array}{c}6.183 \\
( \pm 0.002)\end{array}$ & - & - & - & - & - & 1 & - & 1 & - & - & - & 2 & 0.870 \\
\hline 25 & 3520 & 146 & $\begin{array}{c}4.148 \\
( \pm 0.007)\end{array}$ & 80 & 2 & 1 & 3 & 3.75 & 3 & 1 & 1 & 1 & 1 & 1 & 8 & $5.480^{* *}$ \\
\hline 50 & 3338 & 119 & $\begin{array}{c}3.565 \\
( \pm 0.003)\end{array}$ & 82 & 4 & 2 & 6 & $7.32^{* * *}$ & 5 & 3 & - & - & 2 & 1 & 11 & $9.244^{* * *}$ \\
\hline 75 & 3218 & 66 & $\begin{array}{c}2.051 \\
( \pm 0.004)\end{array}$ & 26 & 2 & 1 & 3 & $11.54^{* * *}$ & 3 & 3 & 2 & 1 & 2 & 2 & 13 & $19.70^{* * *}$ \\
\hline 100 & 3016 & 42 & $\begin{array}{c}1.393 \\
( \pm 0.002)\end{array}$ & 20 & 2 & 1 & 3 & $15.00^{* * *}$ & 2 & 4 & 2 & - & 1 & 3 & 12 & $28.57^{\star * *}$ \\
\hline
\end{tabular}

Values are mean \pm S.E. $(n=3)$, One way ANOVA of mitotic index $\left(F=229460.52^{\circ}\right)$

$\bullet=$ Significant at $p<0.001$

${ }^{* *}=$ Significant from the control $p<0.01\left(x^{2}\right.$ test $)$

${ }^{* * *}=$ Significant from the control $p<0.001\left(x^{2}\right.$ test $)$

While mitotic index in control was $6.183,5.604$, $4.492,3.856$ and 2.321 at various concentration of fertilizer industry effluent showed mitotic index was significantly decreased with increased fertilizer effluent concentration (Table 2). Textile industry effluents also showed chromosomal and mitotic abnormalities such as C-metaphase, bridges laggard, stickiness, unsynchronized and multipolar arrangement of chromosome were observed. However, the frequency of chromosomal and mitotic aberration were increased significantly after treatment with different concentrations of fertilizer industry effluent (Table 2). The percentage of chromosomal aberration was found to be nil in control while $1.25,1.85,2.78$ and 4.55 at 25 , 50,75 and $100 \%$ concentrations of effluent, respectively. The percentage of mitotic aberrant cells at 24 hrs was 0.870 in control and $2.577,5.263,14.286,19.444$ at different fertilizer concentrations of effluent. Chromosomal aberrations like break and fragment were observed whereas aberrations such as C-metaphase, bridges, stickiness, unsynchronized, multipolar arrangement of chromosomes were observed (Table 2) 
Impact of textile and fertilizer industry effluents on cytology

Table 2 Mitotic index and percentage of different abnormalities in root meristem cells of Hordeum vulgare L. treated with different concentrations of fertilizer industry effluent for 24 hour.

\begin{tabular}{|c|c|c|c|c|c|c|c|c|c|c|c|c|c|c|c|c|}
\hline \multicolumn{4}{|c|}{ Mitotic index (\%) } & \multicolumn{5}{|c|}{ Chromosomal aberration } & \multicolumn{8}{|c|}{ Mitotic aberration } \\
\hline 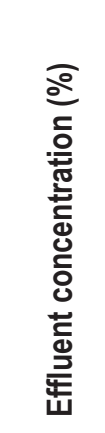 & 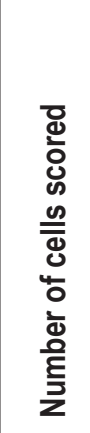 & 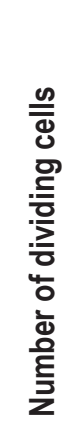 & 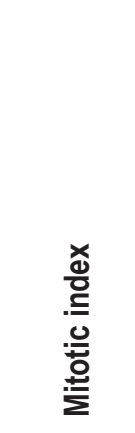 & 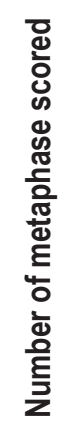 & 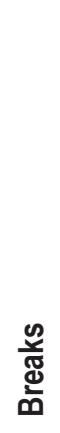 & 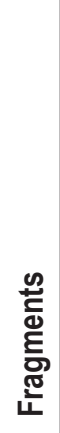 & 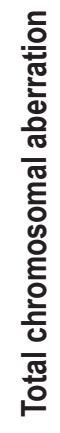 & 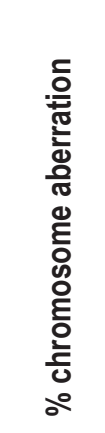 & 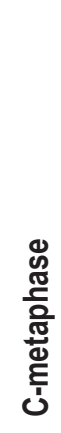 & $\frac{8}{\frac{\delta}{5}}$ & 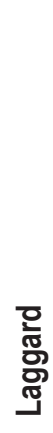 & 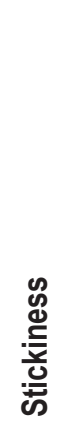 & 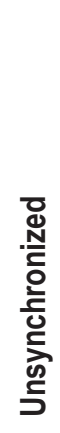 & 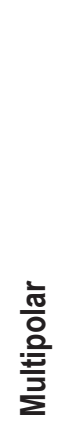 & 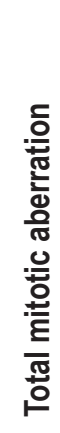 & 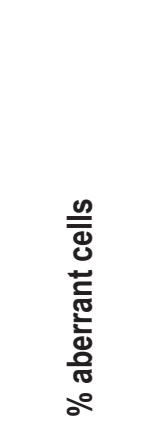 \\
\hline Control & 3720 & 230 & $\begin{array}{c}6.183 \\
( \pm 0.002)\end{array}$ & - & - & - & - & - & 1 & - & 1 & - & - & - & 2 & 0.870 \\
\hline 25 & 3462 & 194 & $\begin{array}{c}5.604 \\
( \pm 0.005)\end{array}$ & 80 & - & 1 & 1 & 1.25 & 3 & - & - & 1 & - & 1 & 5 & 2.577 \\
\hline 50 & 3384 & 152 & $\begin{array}{c}4.492 \\
( \pm 0.004)\end{array}$ & 54 & - & 1 & 1 & 1.85 & 5 & - & - & 1 & - & 2 & 8 & $5.263^{* * *}$ \\
\hline 75 & 3268 & 126 & $\begin{array}{c}3.856 \\
( \pm 0.013)\end{array}$ & 36 & - & 1 & 1 & 2.78 & 7 & 2 & - & 3 & 3 & 3 & 18 & $14.286^{* * *}$ \\
\hline 100 & 3102 & 72 & $\begin{array}{c}2.321 \\
( \pm 0.003)\end{array}$ & 22 & 1 & - & 1 & $4.55^{* *}$ & 8 & 1 & - & 2 & 1 & 2 & 14 & $19.444^{\star \star *}$ \\
\hline
\end{tabular}

Values are mean \pm S.E. $(n=3)$, One way ANOVA of mitotic index $\left(\mathrm{F}=50587.99^{*}\right)$

${ }^{*}=$ Significant at $\mathrm{p}<0.001$

$* *=$ Significant from the control $\mathrm{p}<0.05$ ( $\mathrm{x}^{2}$ test $)$

$* * *=$ Significant from the control $\mathrm{p}<0.001\left(\mathrm{x}^{2}\right.$ test $)$

Results of the present study indicate that effluent of textile industry can induce greater genotoxicity that effects fertilizer industry effluent. Mitotic index decreased progressively with increased effluent concentrations. Similar findings, remove the were already given by Baskar et al. (2002), El-Shahaby et al. (2003), Chandra et al. (2004), Shobha (2004), Sik et al. (2009), Bakare et al. (2009).

\section{Acknowledgements}

Thanks are due to UGC for providing financial assistance to the first author and Head, Botany
Department, Lucknow University, Lucknow for providing Laboratory facilities for the work.

\section{References}

Bakare, A.A., Okunola, A.A., Adetunji, O.A. and Jenmi, H.B. (2009) Genotoxicity assessment of a pharmaceutical effluent using four bioassays. Genet. Mol. Biol., 32, 373-381.

Baskar, S., Rani, M.V. and Usha (2002) Genotoxicity effects of untreated and treated paper mill effluents on the somatic cells of Allium cepa L. Poll. Res., 21, 469-472.

Chandra, R., Kumar, K. and Singh, J. (2004) Impact of anaerobically treated untreated (raw) distillery 
effluent irrigation on soil microflora growth, total chlorophyll and protein contents of Phaseolus aureus L. J. Environ. Biol., 24, 381-385.

Chandra, S., Chauhan, L.K.S., Murthy, R.C., Saxena, P.N., Pande, P.N. and Gupta, S.K. (2005) Comparative biomonitoring of leachates from hazardous solids waste of two industries using Allium test. Sci. Total Environ., 347, 46-52.

Darlington, C.D. and La cour, L. (1976) The handling of chromosomes. Sixth Ed, George Allen and University Ltd., London.

Dewhurst, R.E., Wheeler, J.R., Chummum, K.S., Mathur Ellaghan, A. and Crane, M. (2002) The comparison of rapid bioass for the assessment of urban groundwater quality. Chemosphere., 47, $547-554$
El-Shahaby, O.A., Migid, H.M., Abdel, Soliman, M.I. and Mashaby, I.A. (2003) Genotoxicity screening of industrial waste water using the Allium cepa chromosome aberration assay. Pakistan J. Biol. Sci., 6, 23-25.

Maluszynska, J. and Juchimiuk, J. (2005) Plant genotoxicity a molecular cytogenetic approach in plant bioassays. Plant Genotox., 56, 177-184.

Mumtaz, M.M. (1995) Risk assessment of chemical mixture from a public health perspective. Toxicol. Lett., 82/83, 527-532.

Shobha, J. (2004) Cytotoxic effect of distillery effluent on somatic cells of Allium cepa L. Poll. Res., 23, 303-305.

Sik, L., Acar, O. and Aki, C. (2009) Genotoxicity effects of industrial waste water on Allium cepa L. African J. Biotechnol., 8, 1919-1923. 